\title{
Application Research of Sensitivity Analysis in New Generation Intelligent Substations
}

\author{
Hui Zhu ${ }^{1}$, Guangjin Peng ${ }^{2, *}$, Xiaorui Xing ${ }^{1}$, Chunyan $\mathrm{Jia}^{1}$ and Haiwei $\mathrm{Yu}^{2}$ \\ ${ }^{1}$ Chongqing power company (400 16), No 21, Zhongshan 3rd road, Yuzhong District, Chongqing, China \\ ${ }^{2}$ Chongqing University(400044), No 174, Shazheng Str, Shapingba District, Chongqing, China \\ *Corresponding author
}

\begin{abstract}
Based on sensitivity analysis theory, the technical and economic aspects of a new generation of intelligent substation was researched in this paper. Isolation circuit breaker, land prices and the influence of two factors on the substation investment were our main focuses, we have determined sensitivity analysis indexes according to history cost data, built corresponding economic model and carried out single and dual-factor sensitivity analysis. Analysis results can provide a scientific basis for construction decision-making of a new generation of intelligent substation.
\end{abstract}

Keywords-new generation intellegent substation; sensitivity analysis; technical economy; isolation circuit breaker

\section{INTRODUCTION}

A new generation of intelligent equipment purchasing in higher costs are a key factor in the overall high cost, construction and engineering costs, installation cost and land saving, a new generation of intelligent standing relatively conventional intelligent station have certain advantages. As of right now, as it belongs to a new generation of intelligent station starting stage, many large-scale production of new equipment is not implemented, resulting in equipment purchase costs are too high. However, as a new generation of intelligent standing in nationwide promotion, these new devices will gradually scale production, equipment purchase costs would be reduced on the other, with the perfection of land requisition system in China in recent years, land acquisition price will also continue to improve, which means a new generation of intelligent conservation covers an area of advantage will be more prominent. Therefore, data collected according to the new generation of smart investment, intended to isolate circuit breaker of a new generation of intelligent cost sensitivity analysis and land-use fees.

\section{SENSITIVITY ANALYSIS THEORY}

Sensitivity analysis is a quantitative study of the relevant factors in terms of some kind of variation on one or a set of key indicators of impact of an uncertainty analysis technique, the essence of the change variable values one by one way to explain the key indicators of changes in these factors influence the size of the law. Analyze the selection of main parameters of sensitivity factor. Sensitivity analysis of specific ideas, main uncertainties through research projects change, economic indicators, identify program and analyze the level of sensitivity factor reaches the critical value of the sustainability of the project.

\section{SENSITIVIty ANALYSis OF THE NEW GENERATION INTELLIGENT SUBSTATION}

\section{A. Analysis Method Design}

Select a $220 \mathrm{kV}$ intelligent substation and typical conventional intelligent substations that have been built as the underlying data of sensitivity analysis.

\section{1) Determine sensitivity analysis indexes}

The sensitive analysis objects are concrete technical schemes and their economic benefit. Equipment cost of $220 \mathrm{kV}$ isolation circuit breaker and land acquisition cost are selected as the sensitive analysis indexes in this paper.

\section{2) Determine target value of technical scheme}

Normally, evaluation index value of economic benefit is the target value of technical scheme. Here, we consider the national $220 \mathrm{kV}$ station cost control line 300 yuan $/ \mathrm{kVA}$ as a new generation of intelligent Substation unit capacity investment target value.

\section{3) Determine uncertain factors}

In the sensitivity analysis, it is unnecessary to make all the uncertain factors be considered and calculated, according to the specific circumstances of technical scheme, we just select several factors which have larger change possibility and greater impact on investment target value .

4) Build an economic model

a) Screening independent variables and dependent variables

Select the main cost factors as the independent variable: set every bay cost of the isolation circuit breaker as P1, land acquisition cost as P2, other expenses as Z; Set the main transformer unit capacity cost as the dependent variable $\mathrm{C}$.

b) Constructing function relationship between independent variables and dependent variables

Set up mathematical model as following formula:

$$
C=\alpha P_{1}+\beta P_{2}+Z
$$

Where, $\alpha$ is sensitivity coefficient of $220 \mathrm{kV}$ isolation circuit breaker costs, $\beta$ is sensitivity coefficient of land acquisition cost, $\mathrm{Z}$ is the construction cost except equipment cost of isolation circuit breaker and land acquisition cost. 
5) The Influence degree of uncertainty factors on the analysis index is calculated $l$

\section{B. Single Factor Sensitivity Analysis of Isolation Circuit Breaker Cost}

After estimation of sensitivity coefficients through data analysis, the following formula can be deduced:

$$
C^{\mathrm{x}}=0.292 P_{1}^{\mathrm{x}}+0.043 P_{2}^{\mathrm{x}}+Z^{\mathrm{x}}
$$

Where, $\mathrm{Cx}$ is the unit capacity cost of new generation of intelligent substation, $\mathrm{P} 1 \mathrm{x}, \mathrm{P} 2 \mathrm{x}, \mathrm{Zx}$ are equipment cost of isolation circuit breaker, land acquisition cost and other cost respectively.

Then make sensitivity analysis calculation table, and draw the sensitivity analysis diagram.

TABLE I. SENSITIVITY ANALYSIS CALCULATION TABLE OF ISOLATION CIRCUIT BREAKER COST

\begin{tabular}{|c|c|c|c|c|c|c|c|c|c|}
\hline $\begin{array}{l}\text { Chang } \\
\text { e rate } \\
\text { of } P 1\end{array}$ & $5 \%$ & $\begin{array}{r}\text { I } \\
-\quad \text { I } \\
15 \% \text { I } \\
\end{array}$ & $\begin{array}{l}- \\
24 \\
\% \\
\end{array}$ & $\begin{array}{l}- \\
30 \\
\%\end{array}$ & $\begin{array}{l}- \\
40 \\
\% \\
\end{array}$ & \begin{tabular}{c|} 
\\
$60 !$ \\
\\
\end{tabular} & $\begin{array}{l}- \\
67 \\
\% \\
\end{array}$ & $\begin{array}{lc}1 & - \\
1 & 93 \\
1 & \%\end{array}$ & $\begin{array}{c}- \\
100 \\
\%\end{array}$ \\
\hline $\begin{array}{l}\text { Chang } \\
\text { e rate } \\
\text { of C }\end{array}$ & $-1 \%$ & $-4 \%$ & $-7 \%$ & I-9\% & $\begin{array}{c}- \\
12 \\
\%\end{array}$ & \begin{tabular}{c|}
- \\
18 \\
$\%$ \\
\end{tabular} & $\begin{array}{l}- \\
20 \\
\%\end{array}$ & $\begin{array}{lc}1 & - \\
1 & 27 \\
1 & \%\end{array}$ & $\begin{array}{c}- \\
29 \%\end{array}$ \\
\hline $\begin{array}{c}\text { Variat } \\
\text { ion } \\
\text { amplit } \\
\text { ude of } \\
\text { C } \\
\end{array}$ & -5 & $\begin{array}{r} \\
-14 \\
\end{array}$ & -23 & -28 & -38 & $\begin{array}{r}1 \\
1 \\
-57 \\
\vdots \\
\end{array}$ & -63 & $\begin{array}{ll}1 & \\
1 & \\
1 & -88 \\
1 & -88 \\
1 & \\
1\end{array}$ & -94 \\
\hline $\begin{array}{r}\text { Value } \\
\text { of } C\end{array}$ & 318 & I & 300 & 295 & 285 & 266 & 260 & 235 & 229 \\
\hline
\end{tabular}

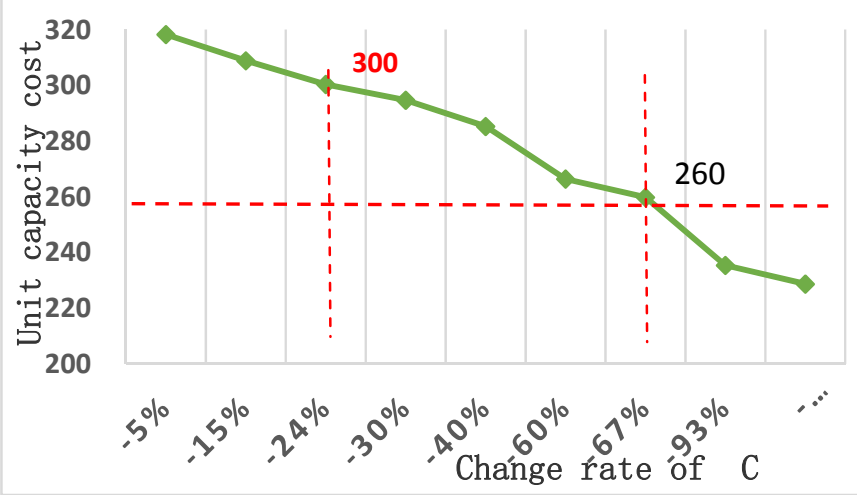

FIGURE I. SENSITIVITY ANALYSIS DIAGRAM OF ISOLATION CIRCUIT BREAKER COST

Through the sensitivity analysis of isolation circuit breaker cost, we can find: without considering other factors, when the equipment price of isolation circuit breaker decrease by $24 \%$ (from the current 3.5 million dropped to 2.66 million yuan), the unit capacity cost will decrease to 300 yuan $/ \mathrm{kVA}$ (that is national cost control line level); when decreased by $67 \%$ (from the current 3.5 million dropped to 1.16 million), the unit capacity cost will decrease to 260 yuan/kVA which is average unit capacity cost of conventional intelligent substation; if the price of isolation circuit breaker continue to fall, new generation of intelligent stations will have lower cost and higher economic value than conventional intelligent substations.

\section{Single Factor Sensitivity Analysis of Land Acquisition Cost}

Using the similar method, the single factor sensitivity analysis of land acquisition cost is carried out.

After estimation of sensitivity coefficients through data analysis, the following formula can be deduced:

$$
C^{\mathrm{c}}=0.0478 P_{1}^{\mathrm{c}}+0.0833 P_{2}^{\mathrm{c}}+Z^{\mathrm{c}}
$$

Where, $\mathrm{Cc}$ is the unit capacity cost of conventional intelligent substation, P1c, P2c, Zc are equipment cost of isolation circuit breaker, land acquisition cost and other cost respectively.

\begin{tabular}{|c|c|c|c|c|c|c|c|c|c|}
\hline & \multicolumn{6}{|c|}{ LAND ACQUISITION COST } & \multicolumn{3}{|c|}{$\Gamma-1$} \\
\hline $\begin{array}{c}\text { Change rate } \\
\text { of } \mathrm{P}_{2}\end{array}$ & $\begin{array}{l}12 \\
0 \\
\% \\
\end{array}$ & $\begin{array}{l}20 \\
0 \\
\%\end{array}$ & $\begin{array}{l}30 \\
0 \\
\%\end{array}$ & $\begin{array}{l}48 \\
0 \\
\%\end{array}$ & $\begin{array}{l}52 \\
0 \\
\%\end{array}$ & $\begin{array}{l}62 \\
0 \\
\%\end{array}$ & $\begin{array}{l}72 \\
0 \\
\%\end{array}$ & 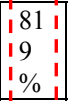 & $\begin{array}{l}10 \\
00 \\
\%\end{array}$ \\
\hline $\begin{array}{c}\text { Change rate } \\
\text { of } C^{\mathrm{X}}\end{array}$ & $\begin{array}{l}5 \\
\%\end{array}$ & $\begin{array}{l}9 \\
\%\end{array}$ & $\begin{array}{l}13 \\
\%\end{array}$ & $\begin{array}{l}21 \\
\%\end{array}$ & $\begin{array}{l}22 \\
\%\end{array}$ & $\begin{array}{l}27 \\
\%\end{array}$ & $\begin{array}{l}31 \\
\%\end{array}$ & {$\left[\begin{array}{lll}1 & 3 & 1 \\
1 & 5 & 1 \\
1 & \% & 1\end{array}\right]$} & $\begin{array}{l}43 \\
\%\end{array}$ \\
\hline $\begin{array}{c}\text { Value of } \mathrm{C}^{\mathrm{x}} \\
\text { (New } \\
\text { generation) }\end{array}$ & $\begin{array}{l}34 \\
0\end{array}$ & $\begin{array}{l}35 \\
1\end{array}$ & $\begin{array}{l}36 \\
5\end{array}$ & $\begin{array}{l}39 \\
0\end{array}$ & $\begin{array}{l}39 \\
5\end{array}$ & $\begin{array}{l}40 \\
9\end{array}$ & $\begin{array}{l}42 \\
3\end{array}$ & 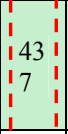 & $\begin{array}{l}46 \\
2\end{array}$ \\
\hline $\begin{array}{c}\text { Change rate } \\
\text { of } C^{\mathrm{C}}\end{array}$ & $\begin{array}{l}10 \\
\%\end{array}$ & $\begin{array}{l}17 \\
\%\end{array}$ & $\begin{array}{l}25 \\
\%\end{array}$ & $\begin{array}{l}40 \\
\%\end{array}$ & $\begin{array}{l}43 \\
\%\end{array}$ & $\begin{array}{l}52 \\
\%\end{array}$ & $\begin{array}{l}60 \\
\%\end{array}$ & 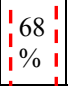 & $\begin{array}{l}83 \\
\%\end{array}$ \\
\hline $\begin{array}{c}\text { Value of } \mathrm{C}^{\mathrm{C}} \\
\text { (Conventio } \\
\text { nal) }\end{array}$ & $\begin{array}{l}28 \\
6\end{array}$ & $\begin{array}{l}30 \\
3\end{array}$ & $\begin{array}{l}32 \\
5\end{array}$ & $\begin{array}{l}36 \\
4\end{array}$ & $\begin{array}{l}37 \\
3\end{array}$ & $\begin{array}{l}39 \\
4\end{array}$ & $\begin{array}{l}41 \\
6\end{array}$ & 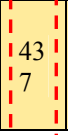 & $\begin{array}{l}47 \\
7\end{array}$ \\
\hline
\end{tabular}

TABLE II. SENSITIVITY ANALYSIS CALCULATION TABLE OF

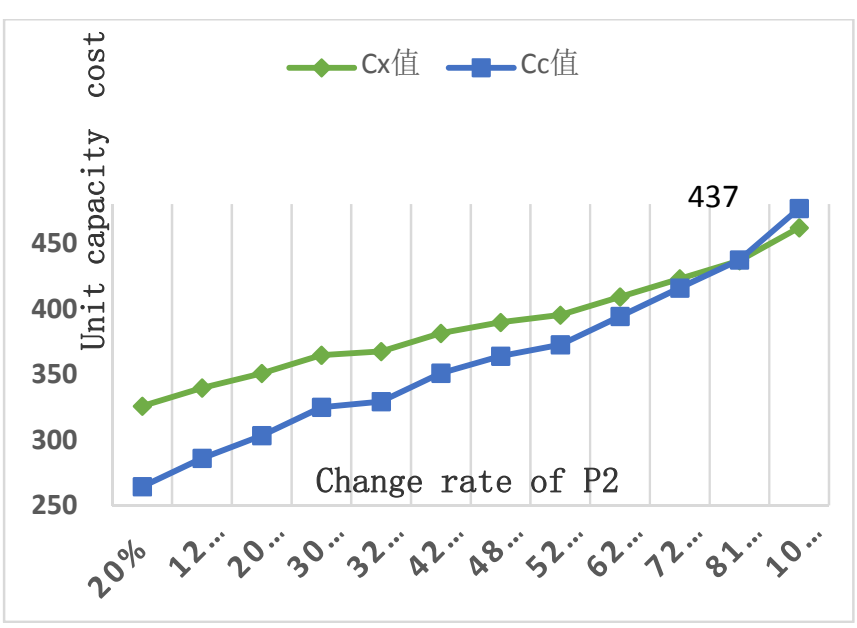

FIGURE II. SENSITIVITY ANALYSIS DIAGRAM OF LAND ACQUISITION COST

Through the sensitivity analysis of land acquisition cost, we can find: when the land acquisition price increase by $819 \%$ (from the current 0.18 million rose to 1.65 million yuan), the unit capacity cost will increase to 437 yuan/kVA, then the unit 
capacity cost of conventional and new generation will be balanced, if the land acquisition price continue to risel, new generation of intelligent stations will have lower cost and higher economic value than conventional intelligent substations.

\section{Dual-Factor Sensitivity Analysis of Isolation Circuit} Breaker Cost and Land Acquisition Cost

Considering the cost change of the isolation circuit breaker and the land acquisition at the same time, the dual-factor sensitivity analysis was carried out, and the results of the dualfactor sensitivity analysis were obtained as follows.

TABLE III. DUAL-FACTOR SENSITIVITY ANALYSIS RESULTS

\begin{tabular}{|c|c|c|c|}
\hline $\begin{array}{c}\text { Land price } \\
\text { (million } \\
\text { Yuan/mu) }\end{array}$ & $\begin{array}{c}\text { Land price } \\
\text { change rate } \\
(\%)\end{array}$ & $\begin{array}{c}\text { Isolation breaker } \\
\text { price change rate } \\
(\%)\end{array}$ & $\begin{array}{c}\text { Unit capacity } \\
\text { cost critical value } \\
\text { (Yuan/kVA) }\end{array}$ \\
\hline 0.18 & 0.00 & -67.00 & 260 \\
\hline 0.20 & $11.11 \%$ & -66.12 & 262 \\
\hline 0.25 & $38.89 \%$ & -64.36 & 268 \\
\hline 0.30 & $66.67 \%$ & -62.22 & 274 \\
\hline 0.35 & $94.44 \%$ & -59.48 & 280 \\
\hline 0.40 & $122.22 \%$ & -55.23 & 286 \\
\hline 0.45 & $150.00 \%$ & -50.00 & 290 \\
\hline 0.51 & $183.33 \%$ & -37.00 & 300 \\
\hline 0.55 & $205.56 \%$ & -33.00 & 305 \\
\hline
\end{tabular}

It can be seen from the table, when the land price increases from 0.18 million Yuan $/ \mathrm{mu}$ gradually, at the same time isolation circuit breaker price decreases, the unit capacity cost of the new generation of intelligent substation can decreased to the level of current cost control line $(300 \mathrm{Yuan} / \mathrm{kVA})$ and conventional intelligent substation. (260Yuan/kVA).

For example, if the land price rose $183.33 \%$, reaching 0.51 million Yuan/mu, the price of isolation circuit breaker decreased by $37 \%$ (from 3.5 million down to 2.2 million Yuan), the unit capacity cost of the new generation of intelligent substation dropped to 300 Yuan $/ \mathrm{kVA}$, if the price of isolation circuit breaker continue to fall, or land price rise further, the new generation of intelligent substation will have better economic benefit and promotion value than conventional intelligent substation.

\section{CONCLUSION}

In this paper, the theory of sensitivity analysis was used to analyze the technical and economic problems of the new generation of intelligent substation, single factor sensitivity and dual factor sensitivity analysis were carried out to evaluate the impact of the isolation circuit breaker cost and land price on the investment level of the new generation of intelligent substations.

Analysis results show that, when the price of isolation circuit breaker decreases and the land price increases to a certain extent, the new generation of intelligent substation will have better economic benefit and promotion value than conventional intelligent substation.

\section{REFERENCES}

[1] Zengjun $\mathrm{Gu}$, "The application of .Excel in profit sensitivity analysis and forecast model" , China management informationization. Changchun,China vol. 11, pp. 64-66, Jan. 2008.

[2] Haitao Si, Study on estimate and Model and Algorithms Used in Power Engineering Cost Based of Small Sample Learning [D].Chongqing:chongqing University, 2010 